\title{
Growth Hormone Signaling Pathway Leading to the Induction of DNA Synthesis and Proliferation in Primary Cultured Hepatocytes of Adult Rats
}

\author{
Kazuki Kurihara ${ }^{1}$, Hajime Moteki $^{1}$, Masahiko Ogihara $^{2}$, and Mitsutoshi Kimura ${ }^{1}$ \\ ${ }^{1}$ Department of Clinical Pharmacology, School of Pharmaceutical Sciences, Josai University, Sakado City, Saitama, \\ Japan; ${ }^{2}$ Laboratory of Clinical Pharmacology, School of Pharmaceutical Sciences, Josai University, Sakado City, \\ Saitama, Japan
}

Corresponding author: Mitsutoshi Kimura, Ph.D., Department of Clinical Pharmacology, School of Pharmaceutical Sciences, Josai University; 1-1 Keyakidai, Sakado City, Saitama 350-0295, Japan; TEL: (+81)-492-71-8078; Fax: (+81)-492-71-8078; email: mkimura@josai.ac.jp

Received, November 10, 2020; Revised, December 26, 2020; Accepted, January 4, 2021; Published, January 8, 2021

\begin{abstract}
Background: We investigated the signal transduction pathway associated with growth hormone (GH)-stimulated DNA synthesis and proliferation in primary cultured hepatocytes. Methods: Adult rat hepatocytes were isolated from normal livers by two-step in situ collagenase perfusion to facilitate disaggregation of the adult rat liver. Then hepatocytes were cultured in serum-free Williams' medium E supplemented with GH $(1-100 \mathrm{ng} / \mathrm{ml})$ in the presence or absence of test reagents. GH-induced hepatocyte DNA synthesis and proliferation were determined, and the phosphorylation activities of Janus kinase (JAK) 2 (JAK2) (p125 kDa), p95-kDa RTK, and ERK1/2 were measured by western blotting. Results: Hepatocytes grown in serum-free defined medium proliferated within $5 \mathrm{~h}$ of culture in the presence of GH $(100 \mathrm{ng} / \mathrm{ml})$ in a concentration- and time-dependent manner $\left(\mathrm{EC}_{50} 75 \mathrm{ng} / \mathrm{ml}\right)$. These proliferative effects of GH were almost completely blocked by an anti-GH receptor monoclonal antibody $(85 \mathrm{ng} / \mathrm{ml})$ and an anti-insulin-like growth factor (IGF)-I receptor monoclonal antibody. In addition, the proliferative effects of GH were significantly blocked by a JAK2 inhibitor (TG101209, $10^{-6} \mathrm{M}$ ), as well as specific signal-transducing inhibitors of phospholipase C (PLC; U-73122, $10^{-6} \mathrm{M}$ ), RTK (AG538, 10 ${ }^{-6} \mathrm{M}$ ), phosphoinositide 3-kinase (PI3K; LY294002, 10 ${ }^{-6} \mathrm{M}$ ), mitogen-activated protein kinase kinase/extracellular signal-regulated kinase (MEK/ERK; PD98059, $10^{-6} \mathrm{M}$ ), and mammalian target of rapamycin (mTOR; rapamycin, $10 \mathrm{ng} / \mathrm{ml}$ ). GH significantly induced the phosphorylations of JAK2 (p125 kDa), p95-kDa IGF-I receptor tyrosine kinase (RTK), and ERK2 in this order according to western blotting analysis. Conclusions: The proliferative action of GH is mediated by two main signaling pathways. One includes activation of the GH receptor/JAK2/PLC/Ca ${ }^{2+}$ pathway, and the other involves activation of the p95-kDa IGF-I RTK/PI3K/ERK2/mTOR pathway in primary cultures of adult rat hepatocytes.
\end{abstract}

\section{INTRODUCTION}

The liver can regenerate by itself following partial hepatectomy or liver damage induced by chemical agents. This process is regulated by hormones, cytokines, endogenous growth factors, and other metabolic processes $(1,2)$. For example, after partial liver resection, cytokines and growth factor receptors activate cellular signal transduction molecules such as tyrosine kinase receptor (RTK), mitogen-activated protein kinase/extracellular signal-regulated kinase (ERK), and transcription factor complex $(3,4)$.

Growth hormone $(\mathrm{GH})$, an anterior pituitary hormone, regulates important physiological processes, including body growth and carbohydrate and lipid metabolism, directly by activating the growth hormone receptor, or indirectly through insulin-like growth factor (IGF)-I (also known as somatomedin $\mathrm{C}$ ), which is produced mainly in the liver in response to GH stimulation (5-7). Moreover, GH plays an important role in liver regeneration, but the molecular signaling mechanisms that are triggered by $\mathrm{GH}$ are not fully understood $(1,2,4,8-10)$.

The GH receptor has been reported to be a member of the cytokine/hematopoietin receptor superfamily (11), which does not have intrinsic tyrosine kinase activity. Conformational changes induced by ligand binding led to activation of 
receptor-associated tyrosine kinases of the Janus kinase (JAK) family. GH receptor activation initiates multiple downstream signals, such as JAK2, signal transducer and activator of transcription (STAT), phosphatidylinositol 3-kinase (PI3K), and ERK, and increases cellular calcium in vitro $(3,4,9,10,12-15)$.

Although hepatocytes from adult rats seldom proliferate in normal physiological conditions, we have demonstrated that DNA synthesis and proliferation are induced in primary parenchymal hepatocytes grown in the presence of growth factors, cytokines, and some autacoids at low cell density (16). Moreover, we have identified the major intracellular signal transduction pathways that are activated by several growth factors, cytokines, and autacoids and that mediate hepatocyte DNA synthesis and proliferation in vitro (17).

The purpose of this study was to investigate whether GH induces hepatocyte DNA synthesis and proliferation during primary culture. We then investigated the role of the JAK2/STAT signaling pathway and the IGF-I RTK/ERK pathway in GH-stimulated hepatocyte DNA synthesis and proliferation.

\section{MATERIALS AND METHODS}

Materials. Human recombinant growth hormone (GH), aphidicolin, and aprotinin were purchased from Sigma Chemical Co. (St. Louis, MO, USA). PD98059 (2'-amino-3'-methoxyflavone) was purchased from Calbiochem-Behring (La Jolla, CA, USA). TG101209 (N-tert-butyl-3 - (5-methyl-2(4-(4-methylpiperazin-1-yl)phenylamino)pyrimidin4-ylamino) benzenesulfonamide) and SH-4-54 (4(N-(4-cyclohexylbenzyl)-2-(2,3,4,5,6- pentafluoro$\mathrm{N}$-methylphenylsulfonamido)acetamido) benzoic acid) were obtained from Med Chem Express (Monmouth Junction, NJ, USA). U-73122 (1-[6-[17 $\alpha$-3-methoxyestra-1, 3, 5(10)-trien-17yl]-amino] hexyl]-1H-pyrrol-2, 5-dione), AG538 ( $\alpha$-Cyano-(3,4 -dihydroxy)cinnamoyl-(3'4'dihydroxyphenyl)ketone), GF109203X (2-[1-(3-dimethyl-aminopropyl)-1H-indol-3-yl]-3(1H-indol-3-yl)maleimide), 2,4-dideoxyadenosine, H-89 (N-[2-(p-bromocinnamylamino) ethyl]-5isoquinolinesulfonamide dihydrochloride), LY294002 (N-[3-chlorophenyl]-6,7-dimethoxy4-quinazolinamine), and rapamycin were obtained from Enzo Life Sciences (Farmingdale, NY, USA). Anti-GH receptor rabbit monoclonal antibody and rabbit IgG monoclonal-isotype control were purchased from Abcam (Cambridge, MA, USA). Monoclonal antibodies against JAK2, phospho-JAK2 $\mathrm{Tyr}^{1007 / 1008}$, EGF receptor, IGF-I receptor, phospho-IGF-I receptor Tyr ${ }^{1316}$, ERK1/2, and phospho-ERK2 $\mathrm{Thr}^{202} / \mathrm{Tyr}^{204}$ were purchased from Cell Signaling Technology (Danvers, MA, USA). Williams' medium E was obtained from Sigma-Aldrich Japan (Tokyo, Japan). Newborn calf serum was obtained from Thermo Fisher Scientific (Tokyo, Japan). Collagenase type II was purchased from Worthington Biochemical Corp. (Lakewood, NJ, USA).

Animals. We purchased Wistar rats (males, weighing 200-220 g) from Tokyo Experimental Animal Co. (Tokyo, Japan). All rats were housed with a 12-h light, 12-h dark cycle with free access to food (standard laboratory diet) and water in a temperature-controlled room. Rats were provided with humane care according to the Guiding Principles for the Care and Use of Laboratory Animals. This study protocol was approved and conducted in accordance with the Institutional Animal Care and Use Committee of Josai University.

Hepatocyte Isolation and Culture. Rats were anesthetized by intraperitoneal injection of 45 $\mathrm{mg} / \mathrm{kg}$ sodium pentobarbital. The method of two-step in situ collagenase perfusion was used for dissociation of rat livers and isolation of hepatocytes (18). More than $97 \%$ of hepatocytes were viable as determined with trypan blue exclusion. Fresh hepatocytes $\left(5.0 \times 10^{4}\right.$ cells $\left./ \mathrm{cm}^{2}\right)$ were plated onto $35-\mathrm{mm} \varnothing$ plastic culture dishes coated with collagen type II (Asahi Glass Co., Tokyo, Japan), and incubated for $3 \mathrm{~h}$ in Williams' medium E containing 5\% newborn calf serum (19). Medium was changed to serum-free Williams' medium E supplemented with human recombinant $\mathrm{GH}(1-100 \mathrm{ng} / \mathrm{ml})$ in the presence or absence of other reagents. The following compounds were then added: GH with or without TG101209 (20), SH-4-54 (21), U-73122 (22), GF109203X (23), and growth-related signal-transducing inhibitors (e.g., AG538 (24), LY294002 (25), PD98059 (26), and rapamycin (27)).

DNA Synthesis and Proliferation of Hepatocytes. DNA synthesis was determined by measuring $\left[{ }^{3} \mathrm{H}\right]$-thymidine incorporation following acid precipitation (19). Specific $\left[{ }^{3} \mathrm{H}\right]$-thymidine 
incorporation was determined by subtracting the value obtained in the presence of aphidicolin (10 $\mu \mathrm{g} / \mathrm{ml}$ ) as a DNA polymerase $\alpha$ inhibitor. To precisely measure hepatocyte proliferation, we counted the nuclei instead of cells. This was performed according to a previously described procedure with minor modification (16), because hepatocytes were firmly attached to the collagen-coated plates and were not quantitively dispersed by EDTA-trypsin treatment. Protein levels were measured with a modified Lowry protein assay with bovine serum albumin (BSA) as the standard (19).

Determination of Phosphorylation Activity of JAK2 (p125 kDa), p95-kDa RTK, and ERK1/2. The anti-phospho-JAK antibody identified a p125-kDa protein as JAK2. To identify JAK2, a cell lysate was prepared. The modified Lowry assay with BSA as the standard was used to assess the protein concentration in the supernatant and cytosolic fraction $(19,28,29)$. Proteins in the supernatant $(30 \mu \mathrm{g} / \mathrm{lane})$ were separated with SDS-PAGE on a $7.5 \%$ polyacrylamide gel in reducing conditions. Separated proteins were transferred to polyvinylidene difluoride membranes. Membranes were blocked for $1 \mathrm{~h}$ at room temperature in TBS (pH 7.4) containing $0.1 \%(\mathrm{v} / \mathrm{v})$ Tween-20 (TBST) in $0.5 \%$ BSA (w/v). The membranes were then incubated overnight at $4^{\circ} \mathrm{C}$ with anti-JAK2 (1:1000) or phospho-JAK2 $\operatorname{Tyr}^{1007 / 1008}$ (1:1000). Membranes were washed in TBST and incubated for $1 \mathrm{~h}$ at room temperature in horseradish peroxidase-conjugated secondary antibody (1:3000 for anti-rabbit IgG or anti-mouse IgG; Rockland, Gilbertsville, PA, USA). Blots were developed using enhanced chemiluminescence substrate (Perkin Elmer, Inc., Hopkinton, MA, USA). Levels of proteins were quantified using densitometry with the Labo-1D image program (Kurabo, Osaka, Japan). The phosphorylated level of the $125-\mathrm{kDa}$ protein was normalized to the total $125-\mathrm{kDa}$ protein level. For $95-\mathrm{kDa}$ RTK, cells were lysed, and proteins in the supernatant $(30 \mu \mathrm{g} / \mathrm{lane})$ were separated with SDS-PAGE on a $10 \%$ polyacrylamide gel. Immunoblotting was performed as described above using anti-phospho-RTK antibody to recognize the $95-\mathrm{kDa}$ IGF-I receptor. Blots were developed and quantified as described above (28). Anti-phospho-95-kDa protein $\mathrm{Tyr}^{1316}$ monoclonal antibody was used as the primary antibody to identify phosphorylated $95-\mathrm{kDa}$ protein, and then the phosphorylated activity of the $95-\mathrm{kDa}$ protein was normalized to the total $95-\mathrm{kDa}$ protein activity. Western blotting, quantification, and normalization of phosphor-ERK1/2 were performed as described above (29). A monoclonal antibody against anti-phospho-ERK1/2 was used to identify phosphorylated ERK isoforms (pERK1; P-p44 MAPK and pERK2; P-p42 MAPK). Data are shown in arbitrary units as means \pm standard error of the mean (SEM). The autoradiograms shown represent 3-4 individual experiments using different preparations of cells.

Data Analysis and Statistics. Data are shown as the means \pm SEM. For group comparisons of unpaired data, analysis of variance followed by the post hoc Dunnett's multiple comparison test were used. Values of $\mathrm{P}<0.05$ were considered statistically significant.

\section{RESULTS}

Time-dependent GH Effects on Hepatocyte DNA Synthesis and Proliferation. We investigated the signal transduction pathway for $\mathrm{GH}$-induced hepatocyte DNA synthesis and proliferation in detail. Three hours after plating, serum-free medium and $100 \mathrm{ng} / \mathrm{ml} \mathrm{GH}$ were added (Fig. 1A and $1 \mathrm{~B}$, arrows). A significant increase in DNA synthesis was first observed about $3.0 \mathrm{~h}$ after the addition of GH, which peaked at about $5.0 \mathrm{~h}$ (Fig. 1A). Significant cell proliferation was seen at $3.5 \mathrm{~h}$, with a peak at about $5 \mathrm{~h}$ (Fig. 1B) compared to corresponding controls. The maximum effects of DNA synthesis and proliferation stimulated by 100 $\mathrm{ng} / \mathrm{ml} \mathrm{GH}$ were about 7.0- and 1.2-fold above baseline, respectively, in this culture period.

Dose-dependent Effects of GH on DNA Synthesis and Proliferation in Hepatocytes.

Dose-dependent effects of $10-1000 \mathrm{ng} / \mathrm{ml} \mathrm{GH}$ on hepatocyte cell proliferation were investigated (Fig. 1C). GH-induced DNA synthesis dose-dependently increased and plateaued at $100 \mathrm{ng} / \mathrm{ml}$. The half-maximal effective concentration $\left(\mathrm{EC}_{50}\right)$ was $42.16 \pm 0.23 \mathrm{ng} / \mathrm{ml}$ for $\mathrm{GH}$. The effects of $\mathrm{GH}$ on the proliferation of hepatocytes $\left(\mathrm{EC}_{50} 44.31 \pm 0.14\right.$ $\mathrm{ng} / \mathrm{ml}$ ) were similar to those on DNA synthesis (Fig.1C).

Dose-dependent Effects of Anti-GH, Anti-IGF-I and Anti-EGF Receptors Monoclonal Antibodies on GH-Induced Hepatocyte DNA Synthesis and Proliferation. To confirm that the GH receptor 
mediates hepatocyte mitogenesis, we investigated the effects of a monoclonal antibody against the $\mathrm{GH}$ receptor on hepatocyte DNA synthesis and proliferation induced by GH. All measurements were made $5 \mathrm{~h}$ after $100 \mathrm{ng} / \mathrm{ml} \mathrm{GH}$ addition. The addition of a monoclonal antibody against the $\mathrm{GH}$ receptor (12.5-80 ng/ml) or IGF-I receptor (12.5-80 $\mathrm{ng} / \mathrm{ml}$ ) dose-dependently inhibited both DNA synthesis and the proliferation of hepatocytes induced by $100 \mathrm{ng} / \mathrm{ml} \mathrm{GH}$ with $\mathrm{IC}_{50}$ values of 50.18 $\pm 0.03 \mathrm{ng} / \mathrm{ml}$ and $50.32 \pm 0.14 \mathrm{ng} / \mathrm{ml}$, respectively (Fig. 1D). As a control, the addition of a monoclonal antibody against EGF receptor $(12.5-80 \mathrm{ng} / \mathrm{ml})$ did not affect either DNA synthesis or the proliferation of hepatocytes induced by 100 ng/ml GH (Fig. 1D). Phase-contrast micrographs of primary cultured hepatocytes showed that hepatocytes proliferated by the addition of 100 $\mathrm{ng} / \mathrm{ml}$ growth hormone (GH) (Fig. 2C) and were inhibited by a monoclonal antibody $(\mathrm{mAb})$ to $\mathrm{GH}$ receptor (Fig. 2D) when compared with corresponding controls (Fig. 2A and 2B).

Effects of Specific Inhibitors of Cell Growth Signal-transducers on GH-induced DNA Synthesis and the Proliferation of Hepatocytes. We then assessed the mitogenic responses of hepatocytes to $100 \mathrm{ng} / \mathrm{ml} \mathrm{GH}$ in combination with
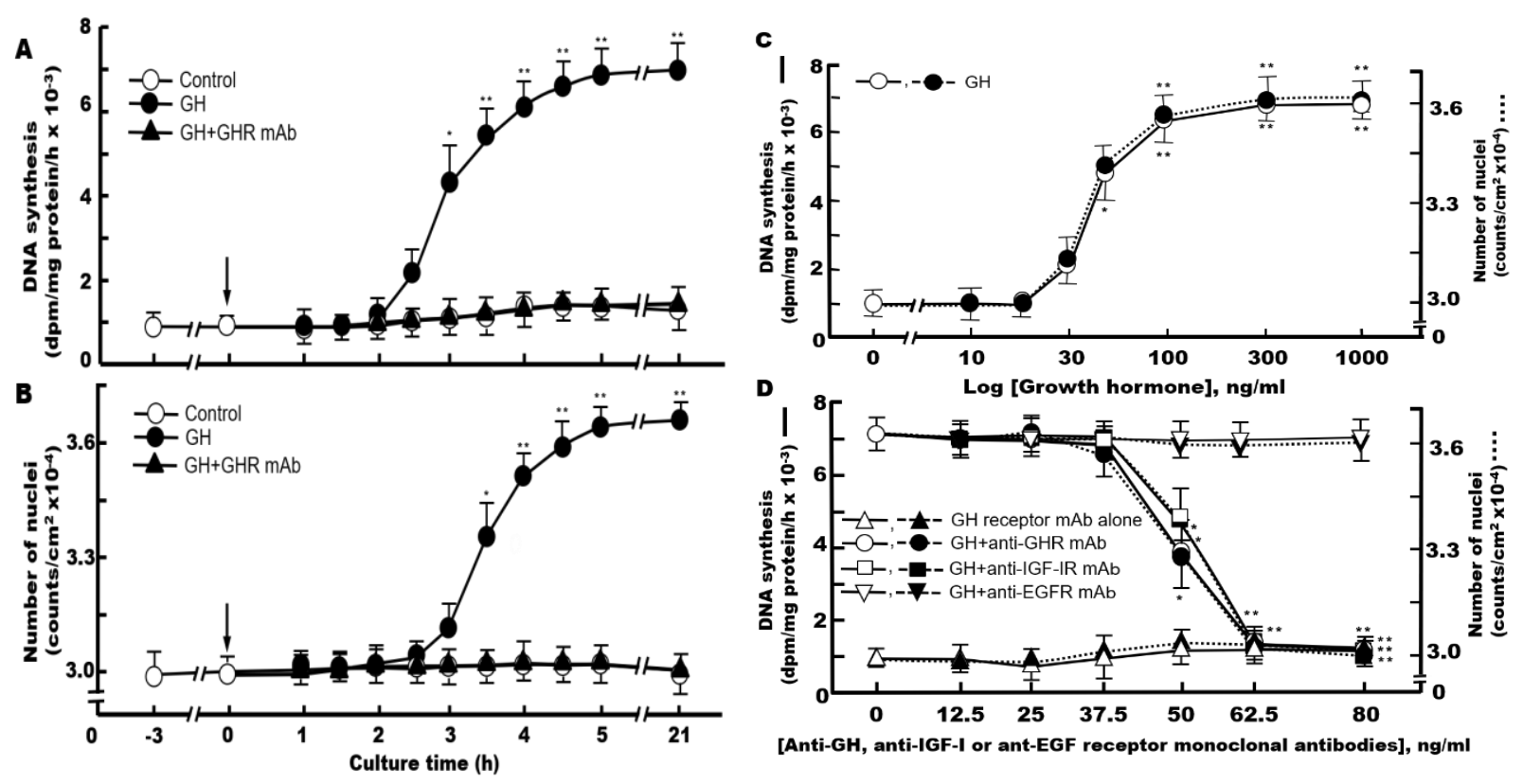

Figure 1. Growth hormone (GH)-induced DNA synthesis and proliferation of primary cultured hepatocytes. Hepatocytes were cultured as described in the Methods. After medium change (time 0), hepatocytes were cultured with $100 \mathrm{ng} / \mathrm{ml} \mathrm{GH}$ with or without anti-GH receptor monoclonal antibody $(60 \mathrm{ng} / \mathrm{ml})$ for $0-21 \mathrm{~h}$. DNA synthesis and proliferation of hepatocytes were determined as explained in the Materials and Methods. Time-course of hepatocyte DNA synthesis (A), proliferation (B), dose-dependence study of GH (C), and dose-dependence studies of anti-GH receptor monoclonal antibody $(\mathrm{mAb})$ or ant-IGF-I receptor mAb (D). Arrows point to the time of $100 \mathrm{ng} / \mathrm{ml} \mathrm{GH}$ addition (A, B). Dose-response effects of $\mathrm{GH}(0-1000 \mathrm{ng} / \mathrm{ml})(\mathrm{C})$, an anti-GH receptor mAb, anti-IGF-I receptor mAb, and anti-EGF receptor $\mathrm{mAb}(12.5-80 \mathrm{ng} / \mathrm{ml})$ on $100 \mathrm{ng} / \mathrm{ml} \mathrm{GH}$-induced hepatocyte DNA synthesis (solid lines) and proliferation (dotted lines) (D) cultured for $5 \mathrm{~h}$. DNA synthesis (solid lines) and proliferation (dotted lines) of hepatocytes were then determined $(\mathrm{C}, \mathrm{D})$. Data are expressed as the means $\pm \mathrm{SEM}$ of three separate experiments. ${ }^{*} \mathrm{P}<$ $0.05, * \mathrm{P}<0.01$ compared with the respective control.

inhibitors of growth-related signal-transducing molecules such as JAK2, STAT1/3, PLC, IGF-I RTK, PI3K, ERK1/2, and/or mTOR. In the absence of GH, $10^{-6}$ M TG101209 (a specific inhibitor of JAK2), $10^{-6}$ M SH-4-54 (a specific inhibitor of STAT1/3), $10^{-6}$ M AG538 (a specific inhibitor of IGF-I RTK), $10^{-6}$ M U-73122 (a specific inhibitor of PLC), $10^{-6} \mathrm{M}$ LY294002 (a specific inhibitor of PI3K), $10^{-6}$ M PD98059 (a specific inhibitor of MEK), and $10 \mathrm{ng} / \mathrm{ml}$ rapamycin (a specific inhibitor of mTOR) had little effect on hepatocyte DNA synthesis and proliferation (Fig. 3A and 3B). In the presence of $100 \mathrm{ng} / \mathrm{ml} \mathrm{GH}$, TG101209 completely blocked GH-stimulated DNA synthesis 
and proliferation of hepatocytes for $5 \mathrm{~h}$ after addition of the reagents, suggesting the involvement of JAK2. In contrast, SH-4-54 did not affect hepatocyte DNA synthesis or proliferation mediated by GH. PLC is involved in GH signaling (30). Thus, the PLC inhibitor U-73122 was tested. U-73122 $\left(10^{-6} \quad\right.$ M) completely inhibited GH-stimulated DNA synthesis and proliferation of hepatocytes (Fig. 3A and 3B). We also tested $10^{-6}$ M AG538 (24), 10 ${ }^{-6}$ M LY294002 (25), 10-6 M PD98059 (26), and $10 \mathrm{ng} / \mathrm{ml}$ rapamycin (27) to investigate the involvement of IGF-I RTK, PI3K, ERK, and mTOR, respectively, on the mitogenic activities of hepatocytes treated with $100 \mathrm{ng} / \mathrm{ml} \mathrm{GH}$. In the absence of $\mathrm{GH}$, these inhibitors did not affect DNA synthesis or cell proliferation of hepatocytes during the first $5 \mathrm{~h}$ in vitro (Fig. $3 \mathrm{~A}$ and $3 \mathrm{~B}$ ). However, in the presence of $100 \mathrm{ng} / \mathrm{ml} \mathrm{GH}$, AG538, LY294002, PD98059, or rapamycin completely blocked the GH-mediated induction of hepatocyte mitogenesis, suggesting roles for IGF-I RTK, PI3K, ERK, and mTOR in these events. As a control, IgG protein $(100 \mathrm{ng} / \mathrm{ml})$ did not affect the $\mathrm{GH}$-induced hepatocyte DNA synthesis and proliferation
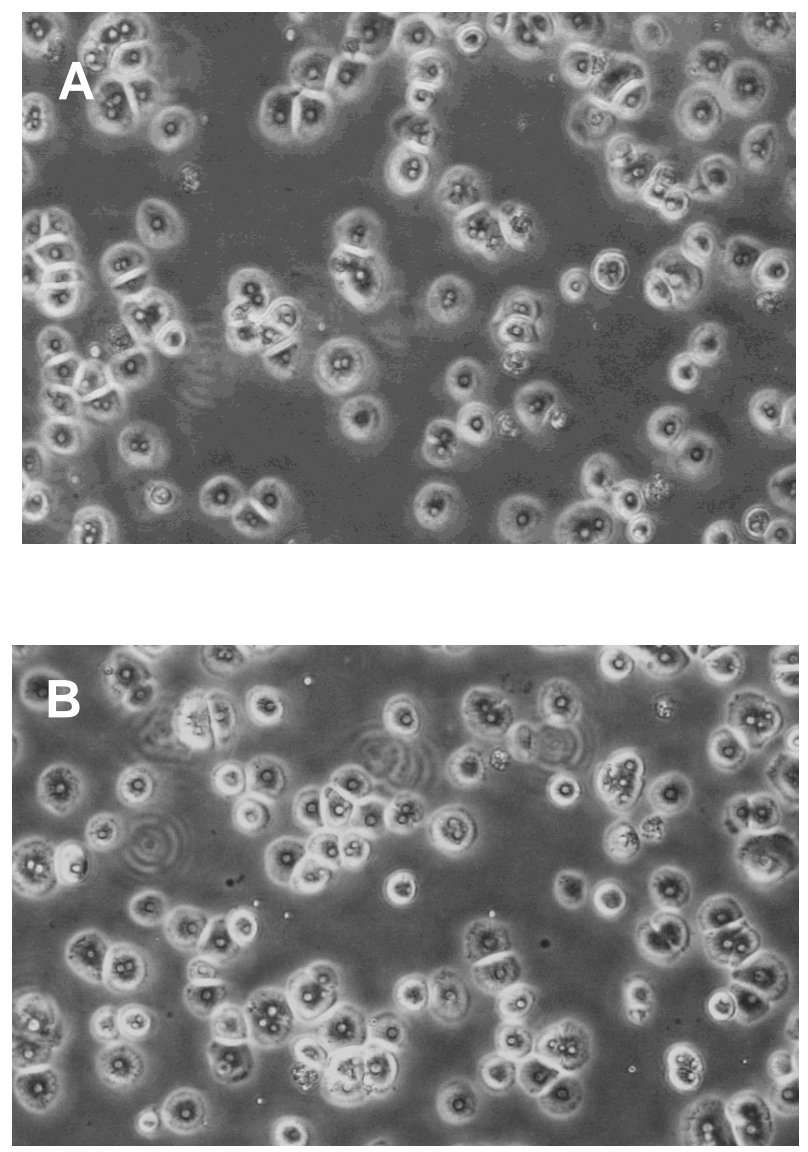
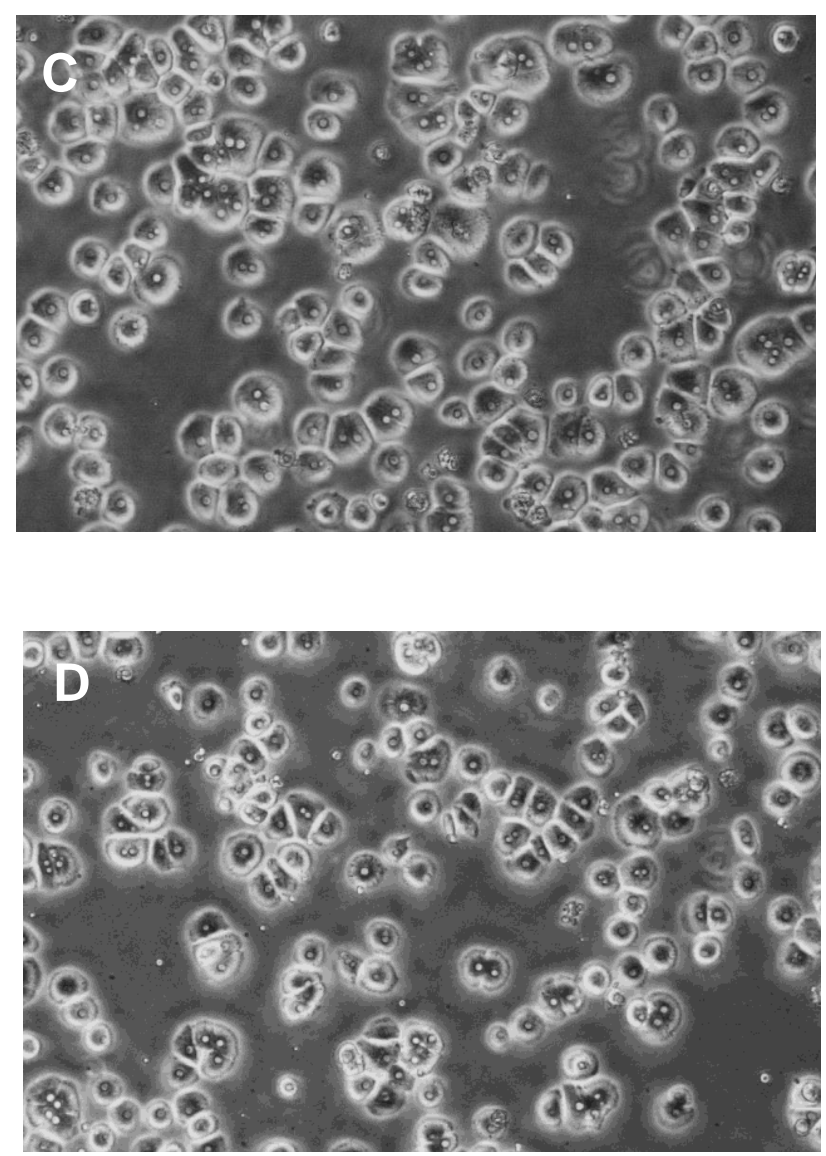

Figure 2. Phase-contrast micrographs of primary cultured hepatocytes stimulated by growth hormone $(\mathrm{GH})$ showing hepatocyte proliferation and its inhibition by a monoclonal antibody (mAb) against $\mathrm{GH}$ receptor. Hepatocytes in Williams' medium E containing 5\% newborn calf serum were plated at a cell density of $5.0 \times$ $10^{4}$ cells $/ \mathrm{cm}^{2}$ and cultured for $3 \mathrm{~h}$. After an adhesion period of $3 \mathrm{~h}$ (time 0 ), the medium was rapidly replaced with serum-free Williams' medium E, and the hepatocytes were cultured with $100 \mathrm{ng} / \mathrm{ml} \mathrm{GH}$ in the absence or presence of test substances for an additional stimulus period. A, control at time $0 ; \mathrm{B}$, control at $5 \mathrm{~h}$; C, $100 \mathrm{ng} / \mathrm{ml} \mathrm{GH}$ at $5 \mathrm{~h}$; D, GH + anti-GH receptor $\mathrm{mAb}$ at $5 \mathrm{~h}$. Scale bar: $200 \mu \mathrm{m}$.

Time-dependent Effects of GH on JAK2 (p-125 kDa) Phosphorylation, and the Effects of Specific Inhibitors of Cell Growth Signal-transducers on GH-mediated JAK2 Phosphorylation. Next, we performed western blotting to examine the time-dependent changes in JAK2 phosphorylation in hepatocytes following GH addition (Fig. 4A). Tyrosine phosphorylation of JAK2 was seen 3-5 min after treatment with 100 $\mathrm{ng} / \mathrm{ml} \mathrm{GH}$, with a peak at $3 \mathrm{~min}$ and a return to the baseline level 60 min after GH treatment (Fig. 4A).

Figure 2 Continues ... 


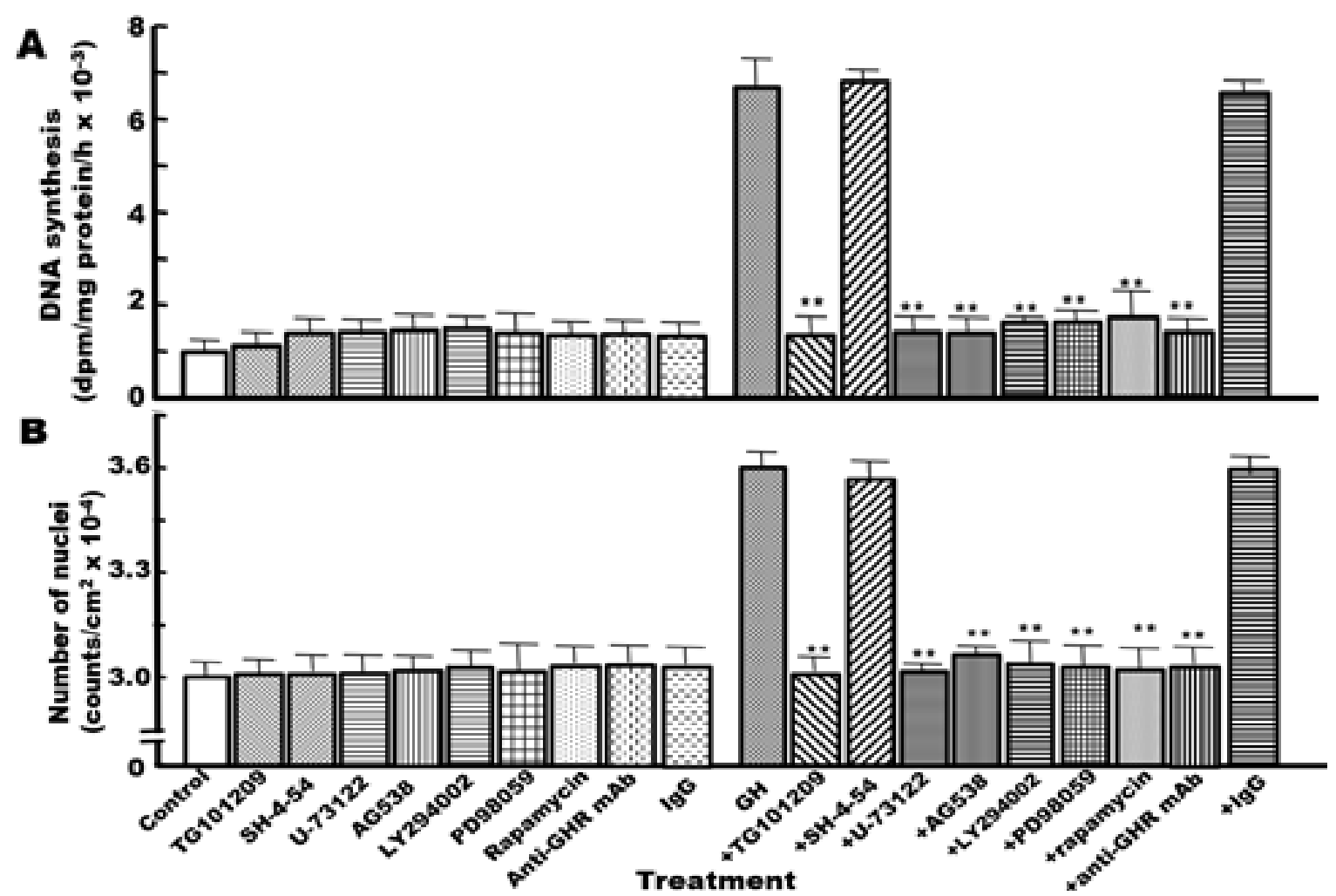

Figure 3. Effects of specific inhibitors of growth-related signal transduction molecules on GH-induced stimulation of hepatocyte DNA synthesis (A) and proliferation (B). After medium change (time 0),Hepatocytes were cultured with or without $100 \mathrm{ng} / \mathrm{ml} \mathrm{GH}$ in the absence or presence of specific inhibitors of cell growth signal-transducers of for an additional $5 \mathrm{~h}$ (see legend to Fig. 1). The concentrations of inhibitors used were as follows: TG101209 $\left(10^{-6} \mathrm{M}\right)$,

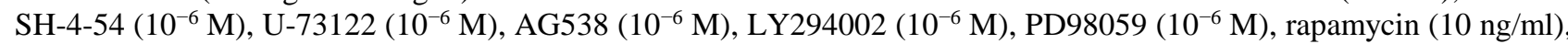
anti-GHR $\mathrm{mAb}(80 \mathrm{ng} / \mathrm{ml})$, and $\mathrm{IgG}(100 \mathrm{ng} / \mathrm{ml})$. Data are expressed as the means \pm SEM of three separate experiments. $* \mathrm{P}<0.05, * \mathrm{P}<0.01$ compared with the respective control.

A
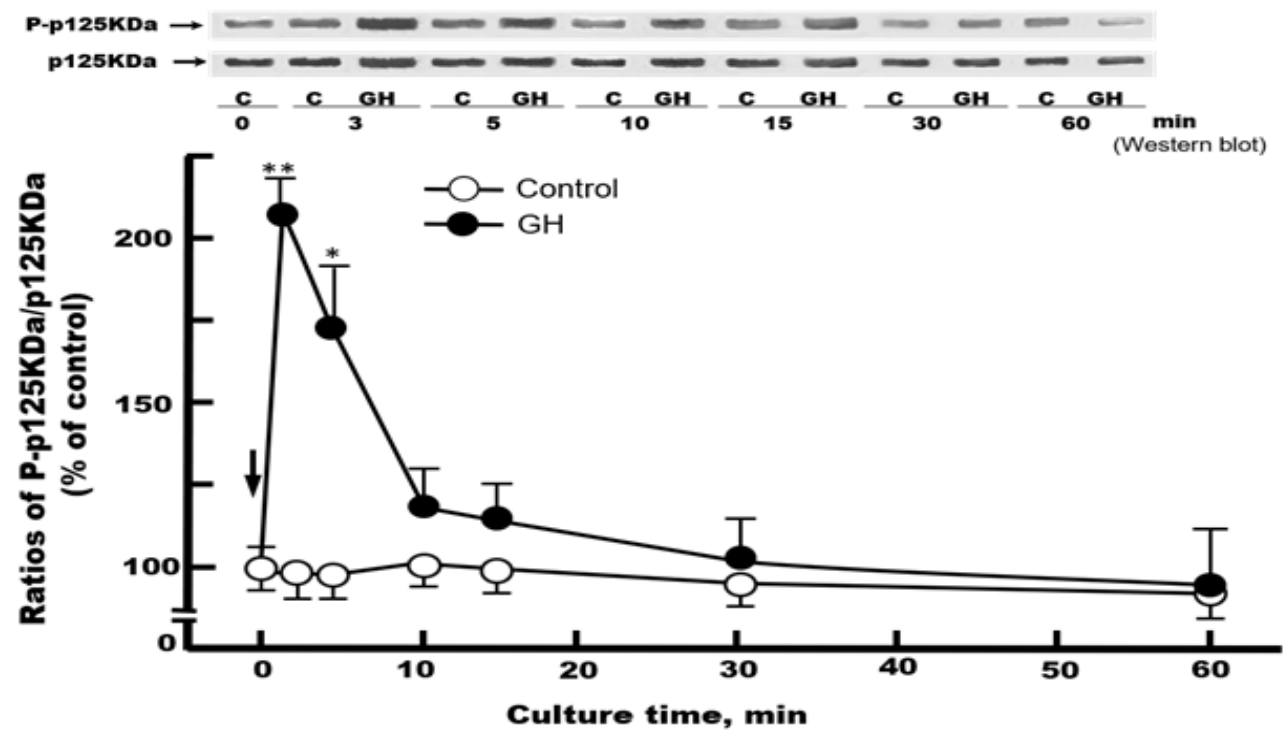

Figure 4 Continues ... 


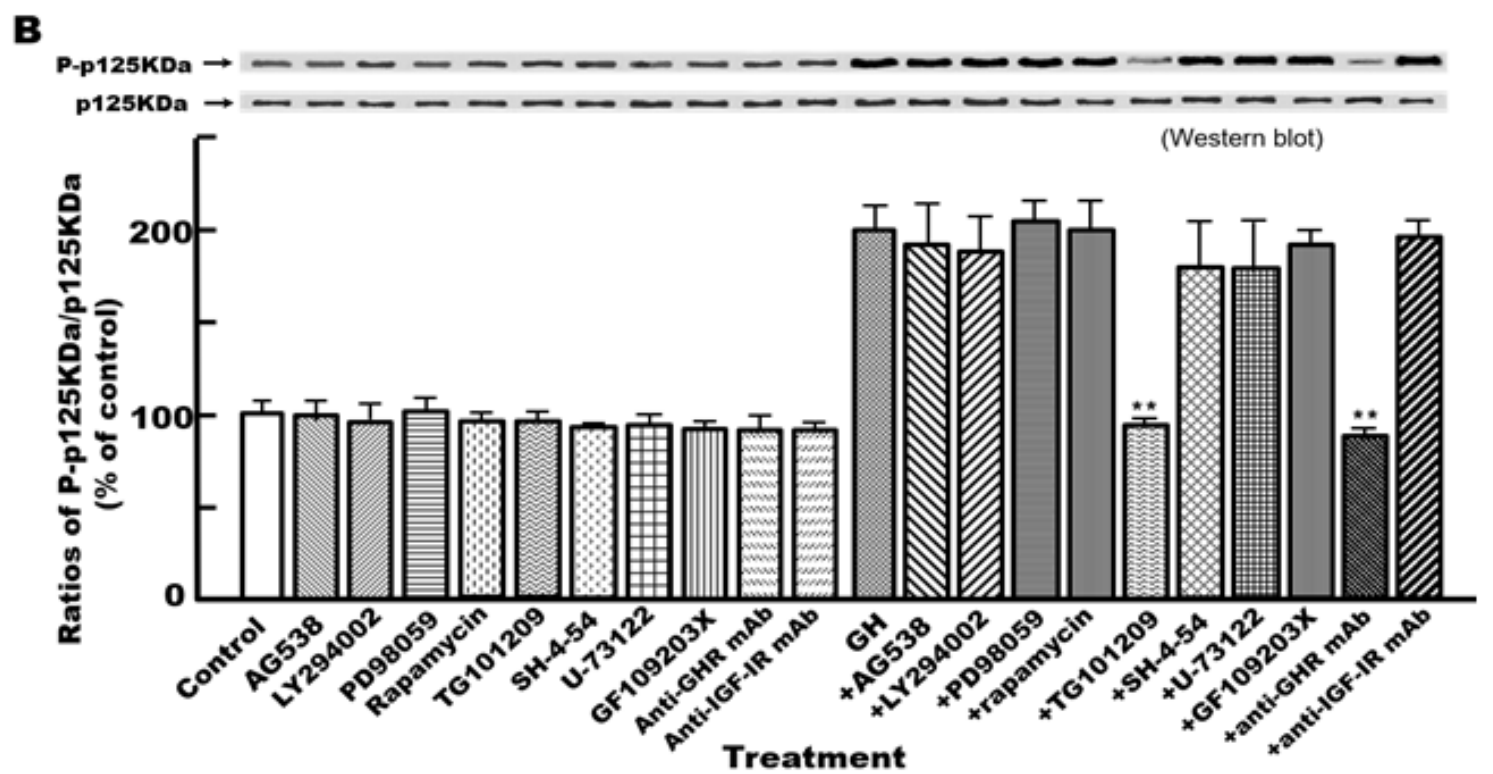

Figure 4. Time-dependent effects of GH on JAK2 (p125 kDa) phosphorylation and the effects of specific inhibitors of cell growth signal-transducers on the phosphorylation of JAK2 induced by GH. Hepatocytes were cultured as described in the legend to Fig. 1. After medium change (time 0), hepatocytes were cultured with or without $100 \mathrm{ng} / \mathrm{ml} \mathrm{GH} \mathrm{for} \mathrm{0-60}$ min. Cell extracts from cultured hepatocytes treated with saline or GH were prepared as described in the Materials and Methods. Western blot image (A, upper panel) and time-course of p125-kDa JAK2 phosphorylation (A, lower panel). Data are shown as a percentage of the individual medium alone as a control (means \pm SEM of three independent experiments). $* \mathrm{P}<0.05, * * \mathrm{P}<0.01$ compared with the control at each time. Arrow: time of GH addition. For inhibitor experiments, hepatocytes were cultured as described in the legend to Fig. 1. After medium change (time 0), hepatocytes were cultured with $100 \mathrm{ng} / \mathrm{ml} \mathrm{GH}$ in the presence or absence of specific inhibitors of cell growth signal-transducers for an additional $3 \mathrm{~min}$. Cell extracts were immunoprecipitated with a JAK2 antibody. Western blot image (B, upper panel) and effects of specific inhibitors on the phosphorylation of p125-kDa JAK2 (ratios of P-p125 kDa/p125 kDa) (B, lower panel). The concentrations of specific inhibitors used were as follows: AG538 (10 $\left.{ }^{-6} \mathrm{M}\right)$, LY294002 (10 $\left.{ }^{-6} \mathrm{M}\right)$, PD98059 $\left(10^{-6} \mathrm{M}\right)$, rapamycin $(10 \mathrm{ng} / \mathrm{ml}), \mathrm{TG} 101209\left(10^{-6} \mathrm{M}\right)$, SH-4-54 (10 $\left.{ }^{-6} \mathrm{M}\right), \mathrm{U}-73122\left(10^{-6} \mathrm{M}\right), \mathrm{GF} 109203 \mathrm{X}\left(10^{-6} \mathrm{M}\right)$, anti-GHR mAb $(80 \mathrm{ng} / \mathrm{ml})$, and anti-IGF-IR mAb $(80 \mathrm{ng} / \mathrm{ml})$. Data are reported as the means \pm SEM of three independent experiments. $* \mathrm{P}<0.05, * * \mathrm{P}<0.01$ compared with medium alone as the control.

Next, we tested the effects of specific inhibitors of cell growth signal-transducers on GH-mediated JAK2 phosphorylation in hepatocytes. When combined, a monoclonal antibody against GH receptor completely blocked the GH-induced JAK2 phosphorylation, but a monoclonal antibody against IGF-I receptor $(80 \mathrm{ng} / \mathrm{ml})$ did not (Fig. 4B). In addition, $10^{-6}$ M TG101209 completely blocked JAK2 phosphorylation, but the other signaling inhibitors $\left(10^{-6} \mathrm{M} \mathrm{SH}-4-54,10^{-6} \mathrm{M}\right.$ AG538, $10^{-6} \mathrm{M}$ LY294002, $10^{-6} \mathrm{M}$ PD98059, and $10 \mathrm{ng} / \mathrm{ml}$ rapamycin) or anti-IGF-I receptor monoclonal antibody (80 ng/ml) did not (Fig. 4B). Thus, following $\mathrm{GH}$ treatment, JAK1/2 activation was upstream of IGF-I RTK, PI3K, ERK, and mTOR, but not STAT3/5. The effects of specific inhibitors of the $\mathrm{PLC} / \mathrm{Ca}^{2+}$ signaling pathway on JAK2 phosphorylation were also examined. Neither $10^{-6}$ M U-73122 nor $10^{-6}$ M GF109203X, a specific inhibitor of protein kinase C (PKC), affected
GH-stimulated JAK2 phosphorylation, suggesting that JAK2 activation occurred upstream of PLC and PKC.

Time-dependent Effects of GH on IGF-I RTK (p95 kDa) Phosphorylation, and the Effects of Specific Inhibitors of Cell Growth Signal-transducers on GH-mediated IGF-I RTK Phosphorylation. We examined whether GH-stimulated hepatocyte DNA synthesis and proliferation are mediated through the IGF-I p95-kDa RTK/ERK1/2 signaling pathway. We tested whether GH induced IGF-I RTK phosphorylation. GH caused an increase in IGF-I RTK phosphorylation, which peaked at a level about 2.4-fold higher than the control (without GH) after 30 min (Fig. 5A). When combined, both a monoclonal antibody against $\mathrm{GH}$ receptor and a monoclonal antibody against IGF-I receptor completely blocked the GH-induced IGF-I RTK 
phosphorylation (Fig. 5B). In addition, the GH-induced increase in IGF-I RTK phosphorylation was completely terminated by $10^{-6}$ M AG538, a specific IGF-I RTK inhibitor. Moreover, the GH-stimulated increase in IGF-I RTK phosphorylation was almost completely obstructed by $10^{-6} \mathrm{M} \mathrm{U}-73122$, suggesting that PLC is upstream of IGF-I RTK (Fig. 5B).

Time-dependent Effects of GH on ERK1/2 Phosphorylation, and the Effects of Specific Inhibitors of Cell Growth Signal-transducers on GH-mediated ERK2 Phosphorylation. We used western blotting to assess the time-dependent effects of GH induction of ERK1/2 phosphorylation in hepatocytes. A band of phosphorylated ERK2 (pERK2) was significantly induced $45 \mathrm{~min}$ after the addition of $100 \mathrm{ng} / \mathrm{ml} \mathrm{GH}$, peaked (about a 2.0-fold increase compared with the basal control) at $45 \mathrm{~min}$ after GH treatment, and then gradually decreased to baseline levels over $60 \mathrm{~min}$ (Fig. 6A). In contrast, ERK1 phosphorylation was not significantly changed in the presence of medium alone as a control or $100 \mathrm{ng} / \mathrm{ml}$ GH (Fig. 6A). When combined, both a monoclonal antibody against GH receptor and a monoclonal antibody against IGF-I receptor completely blocked the GH-induced ERK2 phosphorylation (Fig. 5B). In addition, $10^{-6} \mathrm{M}$

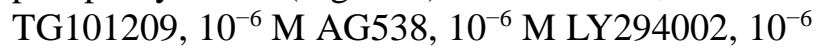
M PD98059, or $10 \mathrm{ng} / \mathrm{ml}$ rapamycin alone did not affect ERK2 phosphorylation (Fig. 6B). TG101209 or PD98059 completely inhibited the GH-induced phosphorylation of ERK2. As expected, SH-4-54 $\left(10^{-6} \mathrm{M}\right)$ did not affect GH-stimulated ERK2 phosphorylation. Moreover, AG538 and LY294002 abolished ERK2 phosphorylation stimulated by GH, suggesting that IGF-I RTK, PI3K, and ERK are downstream of JAK2 signaling. Rapamycin had no effect on ERK2 phosphorylation, indicating that mTOR was downstream of ERK2.

\section{DISCUSSION}

We showed that GH induces DNA synthesis and proliferation during primary cultures of adult rat hepatocytes (Figs. 1A-1C, and 2A-2C). There is a large discrepancy between high rates of DNA synthesis and the moderate increase in number of nuclei. This finding had suggested that other factors or cell conditions are necessary for the cell to achieve adequate proliferation (e.g., $\mathrm{Ca}^{2+}$ concentration in culture medium, cell density, and polyploid) (31). However, the precise reason is not clear at the present time. As shown in Fig. 1D, the addition of a monoclonal anti-GH receptor antibody or anti-IGF-I receptor antibody to the culture dose-dependently blocked the growth-promoting effect of GH on hepatocyte DNA synthesis and proliferation, suggesting that hepatocyte mitogenesis induced by GH is mediated by its own GH receptor and IGF-I receptor (Fig. 1D). It has been reported that activation of the GH receptor by $\mathrm{GH}$ induces three main pathways involved in cell proliferation in the liver in vivo: PI3K/Akt, ERK1/2, and STAT3 $(2,3,14)$. Depending on the cell type, treatment time, and concentration of $\mathrm{GH}$, different intracellular signaling pathways may be activated, thus inducing different short- and long-term effects $(30,32,33)$. However, little is known about the GH signaling pathways in hepatocyte mitogenesis in primary cultures. Therefore, the relative contributions of these signaling pathways on hepatocyte DNA synthesis and proliferation remain to be elucidated.

To further assess the mechanisms of molecular and signal transducing pathways induced by $\mathrm{GH}$, we tested specific inhibitors of signal transducing molecules on GH-mediated hepatocyte DNA replication and cell division. The inhibitor study showed that GH-induced hepatocyte DNA replication and cell division were inhibited by the specific JAK2 inhibitor, TG101209, suggesting that JAK is actually required for GH-stimulated induction of hepatocyte mitogenesis (Fig. 3A and 3B). Several non-RTKs are involved in PLC- $\gamma$ activation. The PLC family is composed of enzymes with various structures and tissue distributions. The subtype of PLC that associates with JAK2 may be PLC- $\gamma(6,34)$. However, the issue of whether PLC is actually involved in the GH-induced JAK pathway during hepatocyte mitogenesis remains unsolved. As shown in Fig. 3A and 3B, U-73122, a specific PLC inhibitor, was found to inhibit GH-induced hepatocyte mitogenesis, suggesting that PLC is involved in GH-induced hepatocyte mitogenesis.

In contrast, STATs can be activated upon binding of ligands to RTKs, G-protein-coupled receptors, and cytokine receptors $(3,4,10,35)$. However, because hepatocyte DNA replication and cell division stimulated by GH were not affected by the specific STAT1/3 inhibitor SH-4-54, activation of STAT1/3 is not likely to be involved in hepatocyte DNA synthesis and cell proliferation during primary culture (Fig. 3). Hepatocyte DNA 


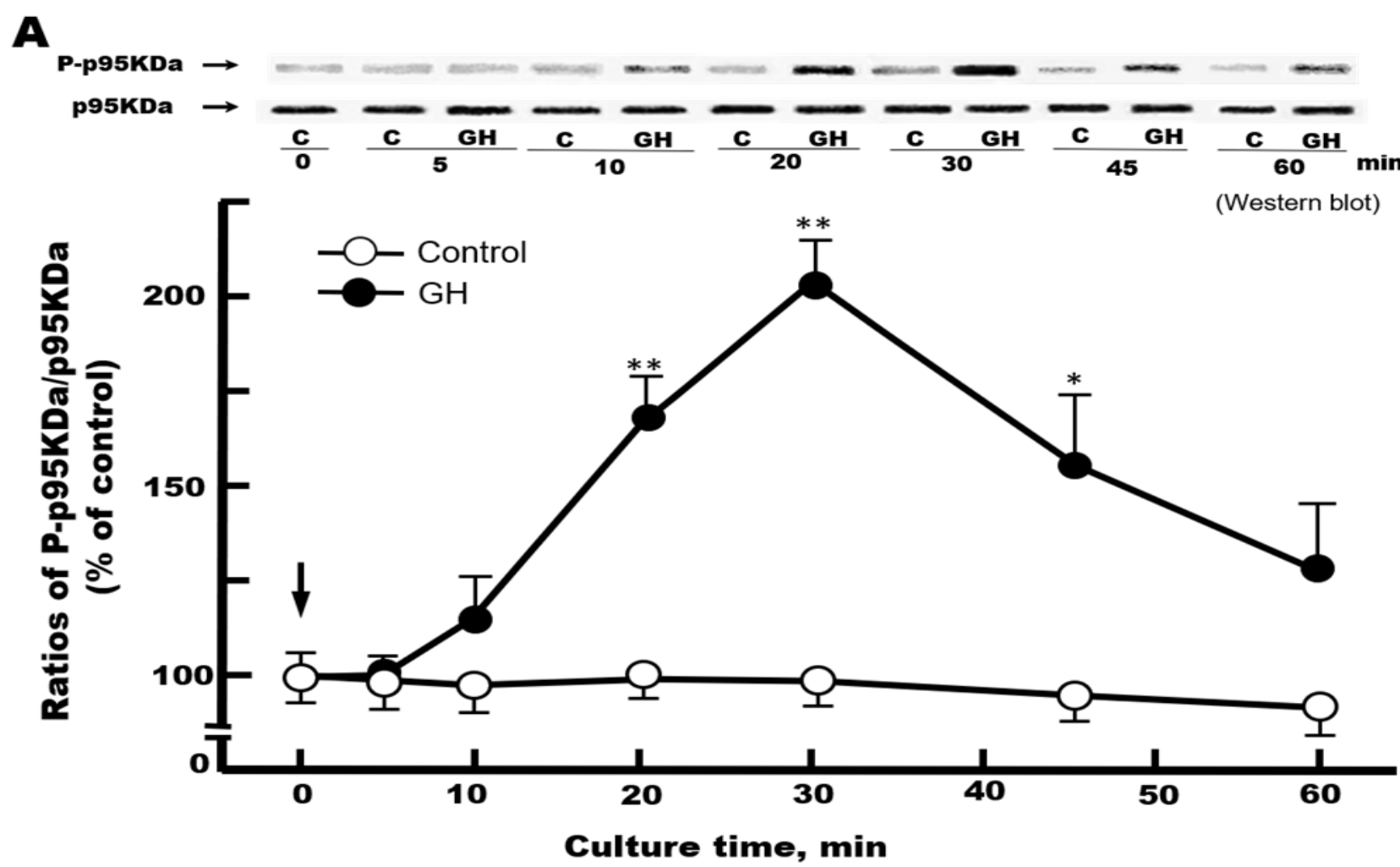

B

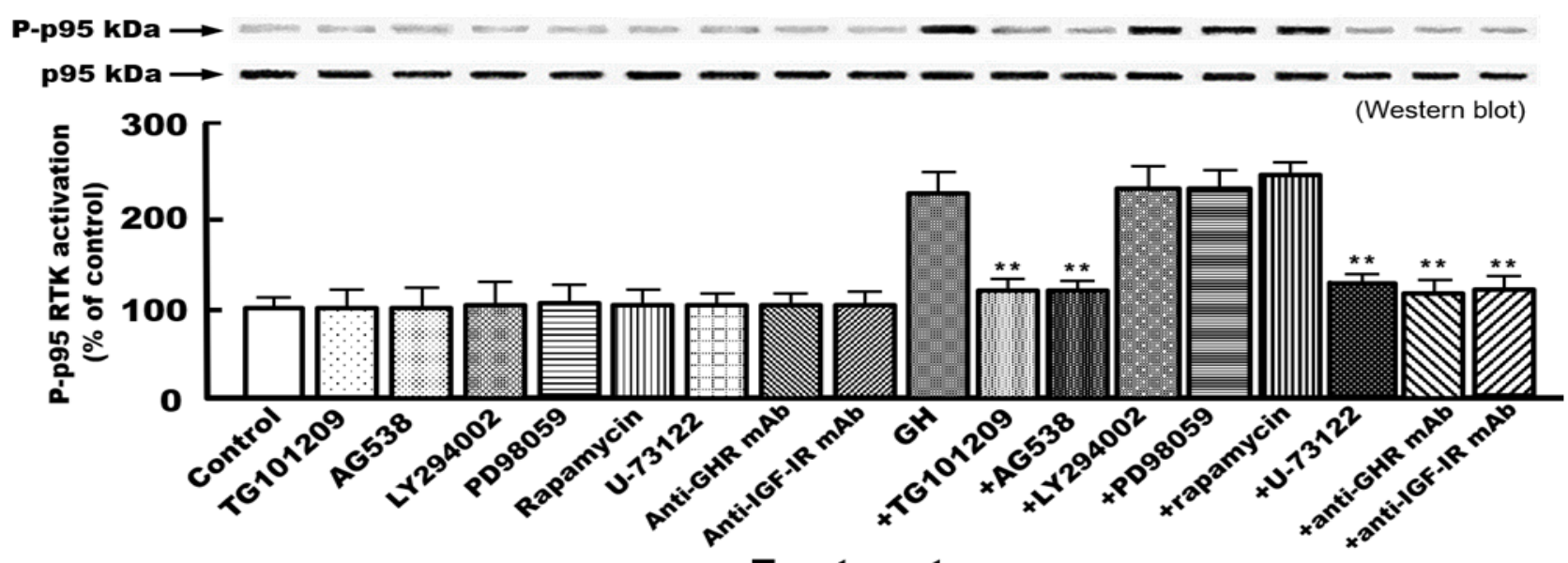

Treatment

Figure 5. Time-dependent effects of GH on IGF-I (p95-kDa) RTK phosphorylation (A) and the effects of specific inhibitors of cell growth signal-transducers on the phosphorylation of IGF-I p95-kDa RTK (B) induced by GH. Hepatocytes were cultured as explained in the legend to Fig. 1. After $3 \mathrm{~h}$ of adhesion (time 0), the medium was rapidly replaced as explained in the legend to Fig. 1. Then, hepatocytes were cultured with or without $100 \mathrm{ng} / \mathrm{ml} \mathrm{GH}$ for 0-60 min. Liver extracts from cultured hepatocytes treated with saline or GH were prepared as explained in the Materials and Methods. Tissue extracts were immunoprecipitated with a p95 IGF-I RTK antibody. Western blot image (A, upper panel) and time-course of p95-kDa IGF-I RTK phosphorylation (A, lower panel). For inhibitor experiments, hepatocytes were cultured as explained in the legend to Fig. 1. After medium change (time 0), hepatocytes were cultured with or without $100 \mathrm{ng} / \mathrm{ml} \mathrm{GH}$ in the presence or absence of specific inhibitors of cell growth signal-transducers for an additional $30 \mathrm{~min}$. Cell extracts were immunoprecipitated with a p95-kDa IGF-I RTK antibody. The concentrations of specific inhibitors used are described in the legend to Figure 4 . Data are reported as the means \pm SEM of three independent experiments. $* \mathrm{P}<0.05, * * \mathrm{P}<0.01$ compared with medium alone as the control. 

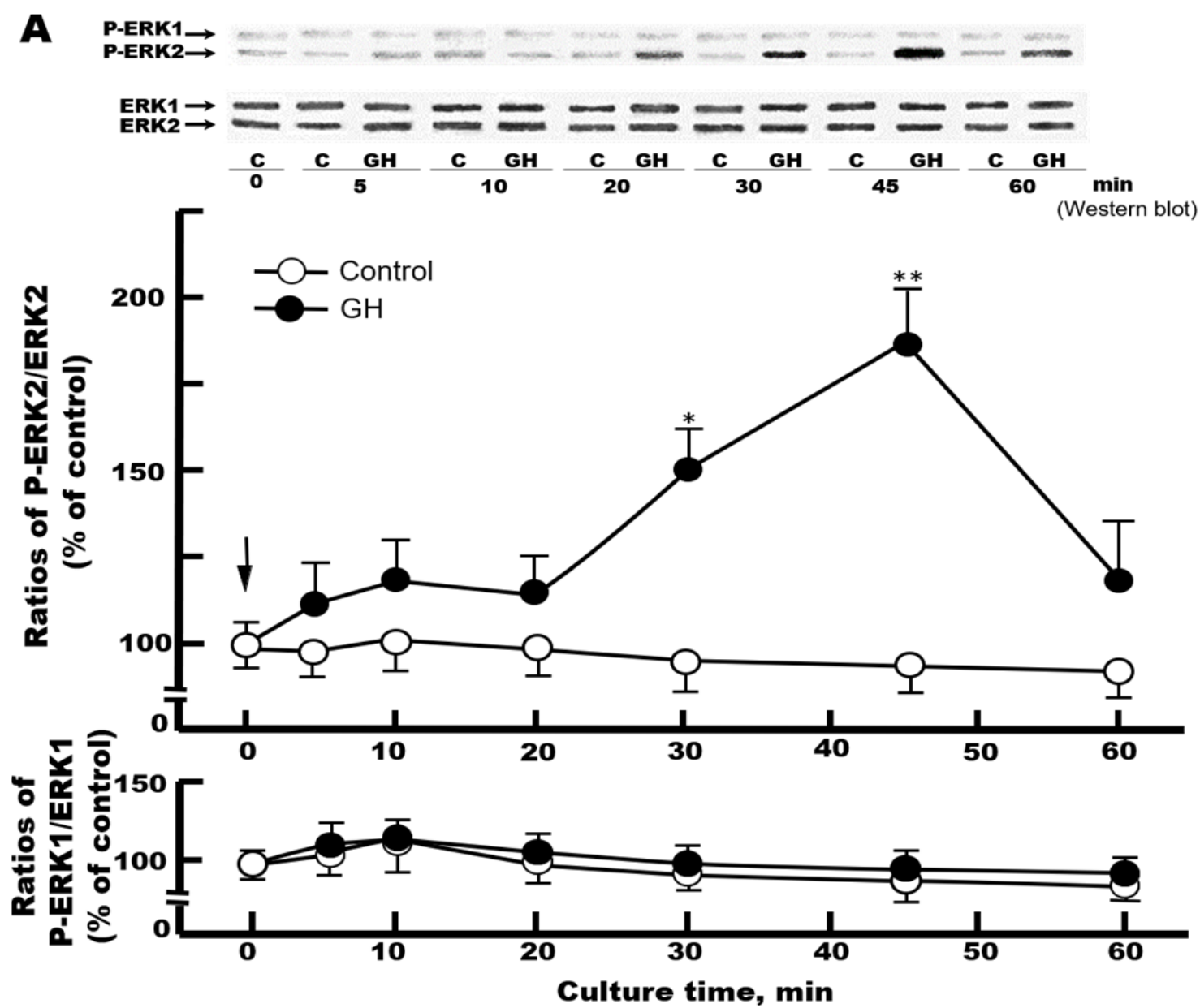

$\mathbf{B}$
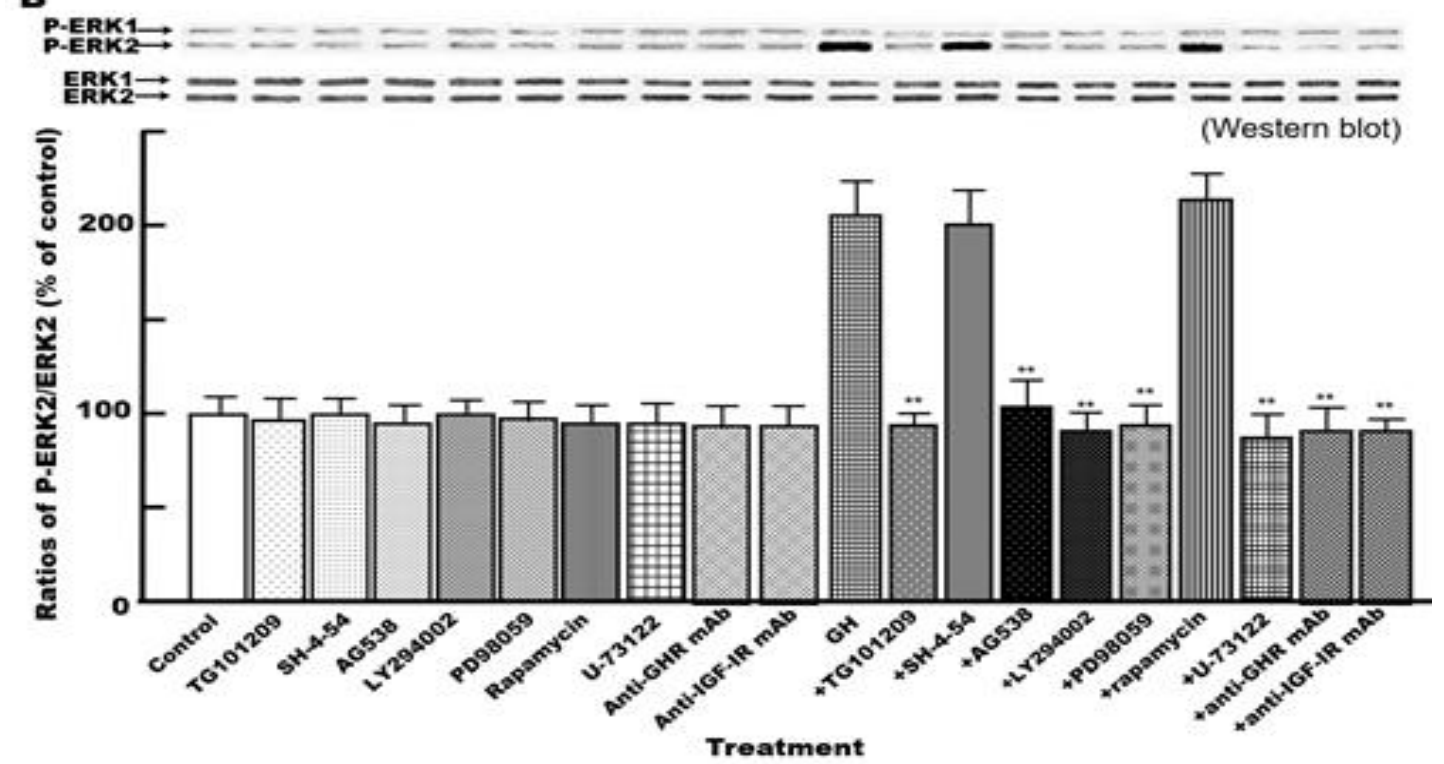

Figure 6. Time-dependent effects of GH on ERK1/2 phosphorylation and the effects of specific inhibitors of cell growth signal-transducers on ERK1/2 phosphorylation induced by GH. Hepatocytes were cultured as explained in the legend to Fig. 1. After medium change (time 0), hepatocytes were cultured with or without $100 \mathrm{ng} / \mathrm{ml} \mathrm{GH}$ for an additional 0-60 min. Phosphorylation of ERK1/2 by GH is described in the Materials and Methods. Tissue extracts were immunoprecipitated

Legend to Figure 6 continues... 
with the ERK1/2 antibody. Time-course of ERK1/2 phosphorylation, western blot image (A, upper panel), time-course of ERK2 phosphorylation (A, middle panel), and time-course of ERK1 phosphorylation (A, lower panel). Data are reported as the means \pm SEM of three independent experiments. $* \mathrm{P}<0.05$, ** $\mathrm{P}<0.01$ compared with the control at the respective time. Arrow: time of GH addition. For inhibitor experiments, hepatocytes were cultured as explained in the legend to Fig. 1. After medium change (time 0), hepatocytes were cultured with or without $100 \mathrm{ng} / \mathrm{ml} \mathrm{GH}$ in the presence or absence of specific inhibitors of cell growth signal-transducers for an additional 45 min. Typical western blot image (P-ERK1/2 and ERK1/2) (B, upper and middle panel) and effects of specific inhibitors on the GH-induced phosphorylation of ERK2 (ratios of P-ERK2/ERK2) (B, lower panel). The concentrations of specific inhibitors used are described in the legend to Figure 4. Data are reported as the means \pm SEM of three independent experiments. $* \mathrm{P}<0.05$, $* * \mathrm{P}<0.01$ compared with the medium alone as the control.

synthesis and proliferation stimulated by GH were also completely inhibited by AG538, an IGF-I RTK inhibitor; LY294002, a PI3K inhibitor; PD98059, an ERK inhibitor; and rapamycin, an mTOR inhibitor (Fig. 3A and 3B), suggesting the involvement of IGF-I RTK, PI3K, ERK, and mTOR in GH-induced hepatocyte mitogenesis.

To obtain further evidence for GH signaling pathway involvement, the time-courses of phosphorylation of JAK2, p95-kDa RTK (IGF-I receptor), and ERK induced by GH were examined to confirm the order of activation of these signal transduction molecules (Figs. 4A, 5A, and 6A). Although GH was continually present, activation of these molecules was rapid and transient, and JAK2, p95-kDa IGF-I-RTK, and ERK reached a peak at 3, 30 , and $45 \mathrm{~min}$, respectively, after the addition of $\mathrm{GH}$, and returned to baseline activity by 10,45 (data not shown), and $60 \mathrm{~min}$, respectively (Figs. $4 \mathrm{~A}, 5 \mathrm{~A}$, and 6A). The time-dependent effects of JAK2, IGF-I RTK, and ERK phosphorylation induced by GH occurred in this order. Early and late time points account for different kinetics of JAK2/PLC and p95-kDa IGF-I-RTK/ERK pathway induction (8).

To further assess the mechanisms of molecular and signal transducing pathways induced by $\mathrm{GH}$, we tested specific inhibitors of signal transducing molecules on GH-mediated phosphorylation of JAK2, p95-kDa RTK (IGF-I receptor), and ERK (Figs. 4B, 5B, and 6B). The inhibitor study showed that GH-induced phosphorylation of JAK2 was inhibited by the specific JAK2 inhibitor, TG101209, suggesting that JAK is actually required for GH-stimulated induction of hepatocyte mitogenesis (Fig. 3A and 3B). To further examine whether the upstream JAK is involved in GH-induced PLC stimulation, the effects of U-73122, a specific PLC inhibitor, on JAK2 phosphorylation were investigated. The result was that U-73122 inhibited the GH-induced hepatocyte mitogenesis (Fig. 3A and 3B) but did not affect JAK2 phosphorylation induced by $\mathrm{GH}$ (Fig. 4B), suggesting that $\mathrm{GH}$ activated downstream PLC via JAK1/2 phosphorylation.

We thus propose a model of GH signaling in which $\mathrm{GH}$ binds to the $\mathrm{GH}$ receptor, mediates the interaction of JAK2 with the GH receptor, and induces tyrosine phosphorylation of the $\mathrm{GH}$ receptor and JAK2. Phosphorylation of the tyrosine residue in the receptor's cytoplasmic domain may produce a binding site for PLC, activation of downstream pathways via increased phosphatidylinositol turnover, and finally, induction of hepatocyte DNA synthesis and proliferation (Fig. 1A and 1B). This reaction may be mediated by a PLC isozyme (possibly PLC- $\gamma$ ) and produces two intracellular second messengers, diacylglycerol and phosphatidylinositol $(1,4,5)$ trisphosphate, which lead to activation of PKC and the release of $\mathrm{Ca}^{2+}$ from intracellular stores, respectively (36). In addition, GH-stimulated JAK phosphorylation was not inhibited by AG538, LY294002, PD98059, or rapamycin (Fig. 4A and 4B), suggesting that PI3K, ERK, and mTOR are downstream elements of p95-kDa IGF-I receptor signaling (Fig. 5B).

Next, we tested specific inhibitors of signal transducing molecules on GH-mediated phosphorylation of p95-kDa IGF-I RTK. When combined, both a monoclonal antibody against GH receptor and a monoclonal antibody against IGF-I receptor completely blocked the GH-induced IGF-I RTK phosphorylation (Fig. 5B). In addition, the GH-induced increase in IGF-I RTK phosphorylation was completely terminated by AG538, a specific RTK inhibitor. Moreover, the GH-stimulated increase in IGF-I RTK phosphorylation was almost completely obstructed by TG101209 and U-73122, suggesting that JAK 2/PLC is upstream of IGF-I RTK (Fig. 5B). In contrast, LY294002, PD98059, and rapamycin did 
not influence the GH-induced IGF-I RTK phosphorylation, suggesting that PI3K, ERK, and mTOR are downstream elements of IGF-I receptor.

Finally, we tested specific inhibitors of signal transducing molecules on GH-mediated phosphorylation of ERK. When combined, both a monoclonal antibody against $\mathrm{GH}$ receptor and a monoclonal antibody against IGF-I receptor completely blocked the GH-induced ERK2 phosphorylation (Fig. 6B). In addition, AG538, LY294002, and PD98059 completely inhibited the GH-induced phosphorylation of ERK2 (Fig. 6B), suggesting that IGF-I RTK, PI3K, and ERK are downstream of GHR/JAK2/PLC signaling. As expected, SH-4-54 did not affect GH-stimulated ERK2 phosphorylation. Rapamycin had no effect on ERK2 phosphorylation, suggesting that mTOR was downstream of ERK2. Taken together, these inhibitor studies show that hepatocyte DNA synthesis and proliferation induced by GH were also mediated by a signal transduction cascade that is associated with p95-kDa IGF-I RTK, PI3K, ERK, and mTOR (37). In agreement with our results, Kilgour et al. showed a requirement for PI3K in GH signaling through ERK and p70 S6K (32).

\section{CONCLUSION}

Our observations showed that GH-induced hepatocyte DNA synthesis and proliferation involve two main signaling pathways in primary cultured hepatocytes. One includes activation of the $\mathrm{GH}$ receptor/JAK2/PLC/Ca ${ }^{2+}$ pathway, and the other involves activation of the p95-kDa IGF-I-RTK/PI3K/ERK2/mTOR pathway (Fig. 7). In the preceding article, we showed that $\mathrm{GH}$ stimulation induces $\mathrm{GH}$ receptor/JAK2/PLC activation, which increases membrane phosphatidylinositol turnover and intracellular $\mathrm{Ca}^{2+}$ levels, resulting in autocrine IGF-I secretion. IGF-I then directly stimulates DNA synthesis and cell proliferation via p95 $\mathrm{kDa}$ IGF-I $\mathrm{RTK} / \mathrm{PI} 3 \mathrm{~K} / \mathrm{ERK} 2 / \mathrm{mTOR}$ signaling in primary cultured hepatocytes (38).

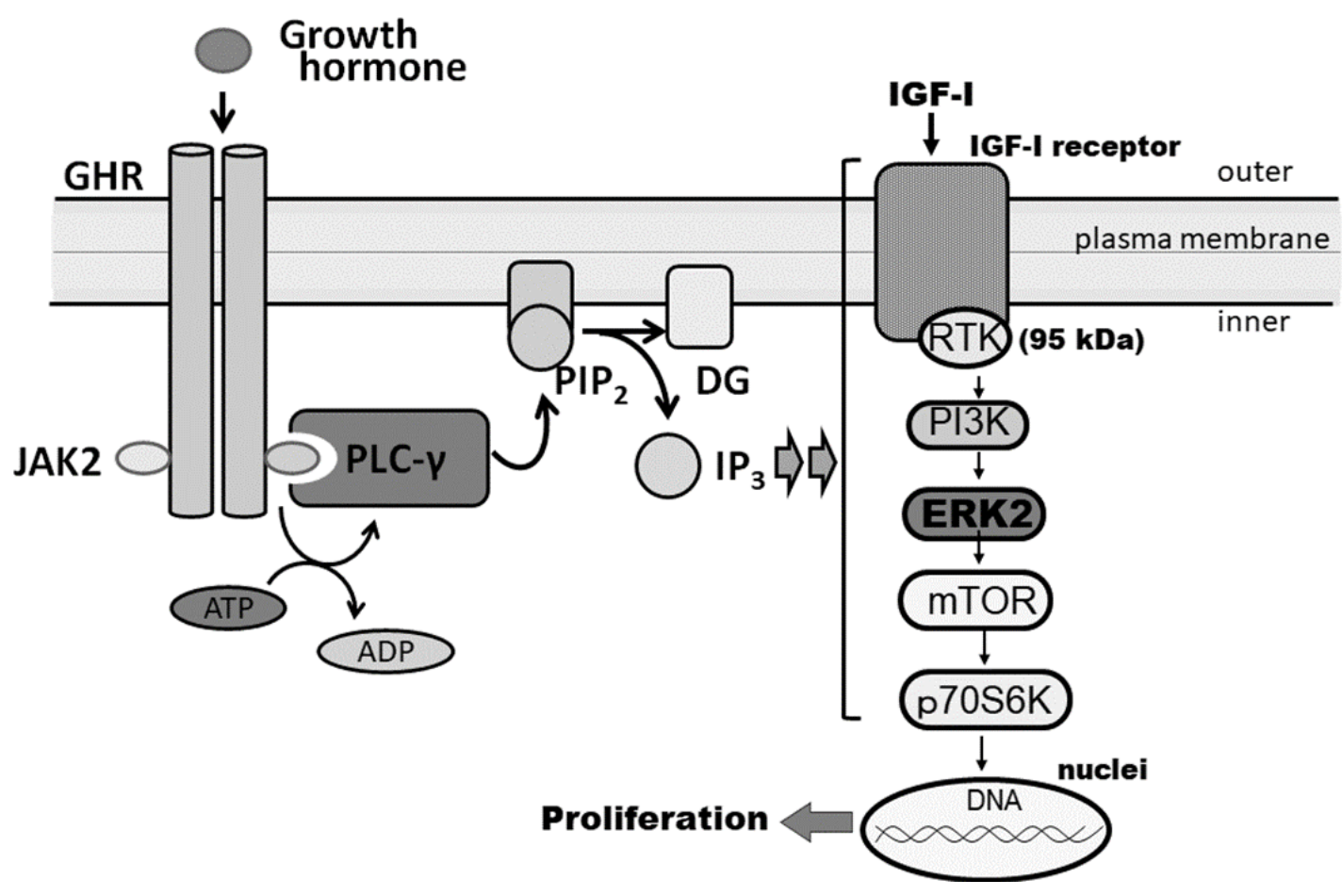

Figure 7. Involvement of the GH receptor/JAK2/PLC pathway and IGF-I-RTK/PI3K/ERK2/mTOR pathway in GH-stimulated hepatocyte DNA synthesis and proliferation. Abbreviations; GH: growth hormone; GHR: growth hormone receptor; JAK2: Janus kinase 2; PLC- $\gamma$ : phospholipase C- $\gamma$; IP $_{3}$ : inositol $(1,4,5)$ trisphosphate; DG: diacylglycerol; IGF-I: insulin-like growth factor-I; RTK: receptor tyrosine kinase; PI3K: phosphoinositide 3-kinase; ERK2: extracellular signal-regulated kinase 2; mTOR: mammalian target of rapamycin; and p70 S6K: ribosomal p70 S6 kinase. 
CONFLICTS OF INTEREST Authors have no conflicts of interest to declare.

\section{REFERENCES}

1. Michalopoulos GK. Liver regeneration. J Cell Physiol, 2007; 213: 286-300. DOI: 10.1002/jcp.21172.

2. Mao SA, Glorioso JM, Nyberg SL. Liver regeneration. Transl Res, 2014; 163: 352-362. DOI: $10.1016 /$ j.trsl.2014.01.005

3. Pennisi PA, Kopchick JJ, Thorgeirsson S, LeRoith D, Yakar S. Role of growth hormone $(\mathrm{GH})$ in liver regeneration. Endocrinology, 2004; 145: 4748-4755. DOI: 10.1210/en.2004-0655

4. Zerrad-Saadi A, Lambert-Blot M, Mitchell C, Bretes H, Collin de I'Hortet A, Baud V, Cheteau F, Sotiropoulos A, Kopchick JJ, Liao L, Xu J, Gilgenkrantz H, Guidotti JE. GH receptor plays a major role in liver regeneration through the control of EGFR and ERK1/2 activation. Endocrinology, 2011; 152: 2731-2741. DOI: 10.1210/en.2010-1193

5. Lund PK, Mosts-Staats BM, Hynes MA, Simmons JG, Jansen M, D' Ercoles AJ, Van Wyk JJ. Somatomedin-C/insulin-like growth factor-I and insulin-like growth factor-II mRNAs in rat fetal and adult tissues. J Biol Chem, 1986; 261: 14539-14544

6. Herrington J, Carter-Su C. Signaling pathways activated by the growth hormone receptor. Trends Endocrinol Metab, 2001; 12: 252-257. doi: 10.1016/s1043-2760(01)00423-4

7. Teran E, Chesner J, Rapaport R. Growth and growth hormone: An overview. Growth Horm IGF Res, 2016; 28: 3-5. DOI: 10.1016/j.ghir.2016.02.004

8. Vanderkuur JA, Butch ER, Waters SB, Pessin JE, Guan K-L, Carter-Su C, Signaling molecules involved in coupling growth hormone receptor to mitogen-activated protein kinase activation. Endocrinology, 1997; 138: 4301-4307. DOI: 10.1210/endo.138.10.5453

9. Thirone AC, Carvalho CR, Saad MJ. Growth hormone stimulates the tyrosine kinase activity of JAK2 and induces tyrosine phosphorylation of insulin receptor substrates and Shc in rat tissues. Endocrinology, 1999; 140: 55-62. DOI: 10.1210/endo.140.1.6417

10. Waters MJ, Hoang HN, Fairlie DP, Pelekanos RA, Brown RJ. New insights into growth hormone action. J Mol Endocrinol, 2006; 36: 1-7. DOI: $10.1677 / \mathrm{jme} .1 .01933$

11. Waters MJ. The growth hormone receptor. Growth Horm IGF Res, 2016; 28: 6-10. DOI: 10.1016/j.ghir.2015.06.001

12. Winston LA, Hunter T. JAK2, Ras, and Raf are required for activation of extracellular signal-regulated kinase/mitogen-activated protein kinase by growth hormone. J Biol Chem, 1995; 270: 30837-30840. DOI: 10.1074/jbc.270.52.30837

13. Carter-Su C, PJ King A, Argetsinger LS, Smit LS, Vanderkuur J, Campbell GS. Signalling pathway of GH. Endocrine J, 1996; 43 (Suppl): S65-S70. DOI: 10.1507/endocrj.43.suppl_s65

14. Li M, Liang X, Kellendonk C, Poli V, Taub R. STAT3 contributes the mitogenic response of hepatocytes during liver regeneration. J Biol Chem, 2002; 277: 28411-28417. DOI: 10.1074/jbc.M202807200

15. Piwien-Pilipuk G, Huo JS, Schwartz J. Growth hormone signal transduction. $\mathrm{J}$ Pediatr Endocrinol Metab, 2002; 15: 771-786. DOI: 10.1515/jpem.2002.15.6.771

16. Kimura M, Ogihara M. Density-dependent proliferation of adult rat hepatocytes in primary culture induced by epidermal growth factor is potentiated by cAMP-elevating agents. Eur J Pharmacol, 1997; 324: 267-276. DOI: 10.1016/s0014-2999(97)00078-2

17. Naito K, Moteki H, Kimura M, Ogihara M. Role of serotonin in liver regeneration. Curr Top Pharmacol, 2019; 23: 39-44.

18. Seglen PO. Preparation of isolated liver cells. Meths Cell Biol, 1975; 13: 29-83. DOI: 10.1016/s0091-679x(08)61797-5

19. Kimura M, Ogihara M. Proliferation of adult rat hepatocytes by hepatocyte growth factor is potentiated by both phenylephrine and metaproterenol. J Pharmacol Exp Ther, 1997; 282: 1146-1154.

20. Pardanani A, Hood J, Lasho T, Levine RL, Martin MB, Noronha G, Finke C, Mak C, Mesa R, Zhu H, Soll R, Gilliland DG, Tefferi A. TG101209, a small molecule JAK2-selective 
kinase inhibitor potently inhibits myeloproliferative disorder-associated JAK2V617F and MPLW515L/K mutations. Leukemia, 2007; 21: 1658-1668. DOI: 10.1038/sj.leu.2404750

21. Haftchenary S, Luchman HA, Jouk AO, Veloso AJ, Page BD, Cheng XR, Dawson SS, Grinshtein N, Shahani VM, Kerman K, Kaplan DR, Griffin C, Aman AM, Al-Awar R, Weiss S, Gunning PT. Potent Targeting of the STAT3 Protein in Brain Cancer Stem Cells: A Promising Route for Treating Glioblastoma. ACS Med Chem Lett, 2013; 8: 1102-1107. DOI: $10.1021 / \mathrm{ml} 4003138$

22. Smith RJ, Sam LM, Justen JM, Bundy GL, Bala GA, Bleasdale JE. Receptor-coupled signal transduction in human polymorphonuclear neutrophils: effects of a novel inhibitor of phospholipase C-dependent processes on cell responsiveness. J. Pharmacol. Exp. Ther., 253, 688-697 (1990).

23. Hauss P, Mazerolles F, Hivroz C, Lecomte O, Barbat C, Fischer A. GF109203X, a specific PKC inhibitor, abrogates anti-CD3 antibody-induced upregulation of CD4+ $\mathrm{T}$ cell adhesion to B cells. Cell Immunol, 1993; 150: 439-446. DOI: 10.1006/cimm.1993.1211

24. Blum G, Gazit A, Levitzki A. Development of new insulin-like growth factor-1 receptor kinase inhibitors using catechol mimics. J Biol Chem, 2003; 278: 40442-4054. DOI: 10.1074/jbc.M305490200

25. Shoba LN, Newman M, Liu W, Lowe WL Jr. LY 294002, an inhibitor of phosphatidylinositol 3-kinase, inhibits GH-mediated expression of the IGF-I gene in rat hepatocytes. Endocrinology, 2001; 142: 3980-3986. DOI: 10.1210/endo.142.9.8394

26. Li X, Huang Y, Jiang J, Frank SJ. ERK-dependent threonine phosphorylation of EGF receptor modulates receptor downregulation and signaling. Cell Signal, 2008; 20: 2145-2155. DOI: 10.1016/j.cellsig.2008.08.006

27. Dixon M, Agius L, Yeaman SJ, Day CP. Inhibition of rat hepatocyte proliferation by transforming growth factor beta and glucagon is associated with inhibition of ERK2 and p70 S6 kinase. Hepatology, 1999; 29: 1418-1424.
DOI:

DOI: 10.1248/bpb.b15-0092310.1002/hep.51029051 6

28. Hernández-Sánchez C, Blakesley V, Kalebic T, Helman L, LeRoith D. The Role of the Tyrosine Kinase Domain of the Insulin-Like Growth factor-I Receptor in Intracellular Signaling, Cellular Proliferation, and Tumorigenesis. J Biol Chem, 1995; 270: 29176-29181. DOI: $10.1074 / j b c .270 .49 .29176$

29. Naito K, Moteki H, Kimura M, Natsume H, Ogihara M. Serotonin 5-HT2B Receptor-Stimulated DNA Synthesis and Proliferation Are Mediated by Autocrine Secretion of Transforming Growth Factor- $\alpha$ in Primary Cultures of Adult Rat Hepatocytes. Biol Pharm Bull, 2016; 39: 570-577. DOI: 10.1248/bpb.b15-00923

30. Marrero I, Déniz A. The phospholipase C-InsP3 pathway is involved in calcium mobilization induced by growth hormone in hepatocytes. Growth Horm IGF Res, 2004; 14: 85-90. DOI: 10.1016/j.ghir.2003.11.001

31. McGowan, J.A, Hepatocyte proliferation in culture: Guillouzo A and Guguen-Guillouzo C. (eds), Research in Isolated and Cultured Hepatocytes, John Libbey Eurotext Ltd./INSERM, pp.13-38, 1986.

32. Kilgour E, Gout I, Anderson NG. Requirement for phosphoinositide 3-OH kinase in growth hormone signaling to the mitogen-activated protein kinase and p70s6k pathways. Biochem J, 1996; 315: 517-522. DOI: 10.1042/bj3150517

33. Pilecka I, Whatmore A, van Huijsduijnen RH, Destenaves B, Clayton P. Growth hormone signalling: sprouting links between pathways, human genetics and therapeutic options. Trends Endocrinol Metab, 2006; 18: 12-18. DOI: 10.1016/j.tem.2006.11.004

34. Rhee SG, Bae YS. Regulation of phosphoinositide-specific phospholipase C isozymes. J Biol Chem, 1997; 272: 15045-15048. DOI: $10.1074 /$ jbc.272.24.15045

35. Brooks AJ, Wooh JW, Tunny KA, Waters MJ. Growth Hormone receptor; mechanism of action. Int $\mathrm{J}$ Biochem Biol, 2008; 40: 1984-1989. DOI: 10.1016/j.biocel.2007.07.008 
36. Scharenberg AM, Kinet JP. Ptdins-3,4,5-P3: a regulatory nexus between tyrosine kinases and sustained calcium signals. Cell, 1998; 94: 5-8. DOI: 10.1016/s0092-8674(00)81214-3

37. Kimura M, Ogihara M. Effects of insulin-like growth factor I and II on DNA synthesis and proliferation in primary cultures of adults rat hepatocytes. Eur J Pharmacol, 1998; 354: 271-281. DOI: 10.1016/s0014-2999(98)00455-5

38. Kurihara K, Moteki H, Kimura M, Ogihara M. Autocrine secretion of insulin-like growth factor-I mediates growth hormone-stimulated DNA synthesis and proliferation in primary cultures of adult rat hepatocytes. Eur J Pharmacol, 2021; 891: 173753 DOI:10.1016/j.ejphar.2020.173753 